\title{
PENGARUH KEDISIPLINAN DAN PELATIHAN KERJA TERHADAP KINERJA PEGAWAI
}

\section{Effect Of Discipline And Vocational Training On Employee Performance}

\author{
Irawati Nur \\ Email: irawatinur77@gmail.com \\ Akademi Sekretari dan Manajemen Amsir Parepare \\ Jalan Andi Sapada No.11 Parepare
}

\begin{abstract}
ABSTRAK
Tujuan dari penelitian ini adalah untuk mengetahui Pengaruh Kedisiplinan dan Pelatihan Kerja secara parsial dan secara simultan terhadap Kinerja Pegawai. Variabel bebas dalam penelitian ini adalah Kedisiplinan dan Pelatihan Kerja sementara variabel terikat adalah Kinerja Pegawai. Penelitian ini dilakukan pada Pegawai UPTD Pemadam Kebakaran Kabupaten Sidrap dengan jumlah sampel 56 orang. Jenis penelitian yang digunakan adalah penelitian kuantitatif. Metode pengumpulan data yang digunakan adalah observasi, wawancara, serta kuesioner (angket). Untuk analisis data menggunakan : uji validitas, uji realibilitas, uji parsial, uji simultan, regresi linear berganda dan uji koefisien determinasi. Hasil penelitian menunjukkan bahwa secara parsial dan simultan variabel kedisiplinan dan pelatihan kerja terhadap kinerja pegawai berpengaruh positif dan signifikan.
\end{abstract}

\section{Kata kunci : Kedisiplinan, Pelatihan Kerja, dan Kinerja}

\begin{abstract}
The purpose of this study was to determine the Effect of Discipline and Job Training partially and simultaneously on Employee Performance. The independent variables in this study are Discipline and Job Training while the dependent variable is Employee Performance. This research was conducted on the staff of the Sidrap District Fire Department with a total sample of 56 people. This type of research is quantitative research. Data collection methods used were observation, interview, and questionnaires. For data analysis using: validity test, reliability test, partial test, simultaneous test, multiple linear regressions and the coefficient of determination test. The results showed that partially and simultaneously the discipline and job training variables on employee performance had a positive and significant effect.
\end{abstract}

Keywords : Discipline, Job Training, Performance

\section{PENDAHULUAN}

Sumber Daya Manusia (SDM) merupakan aset perusahaan yang paling mahal dibanding dengan aset-aset lain karena SDM merupakan penggerak utama organisasi perusahaan. SDM 
harus dikelola secara optimal, continue dan diberi ekstra perhatian dan memenuhi hak-haknya, selain itu SDM merupakan patner pengusaha untuk mencapai tujuan organisasi. Dengan demikian SDM harus selalu meningkatkan kompetensinya, seiring dengan perkembangan era globalisasi.

Agar dapat bersaing dalam persaingan bisnis perusahaan dituntut untuk memperoleh, mengembangkan, dan mempertahankan Sumber Daya Manusia yang berkualitas. Dengan meningkatnya kualitas Sumber Daya Manusia diharapkan karyawan dapat bekerja secara produktif dan profesional sehingga kinerja yang dicapainya diharapkan akan lebih memuaskan sesuai standar kerja yang dipersyaratkan.

Untuk mencapai standar kinerja yang memuaskan diperlukan kemampuan profesional dan untuk mencapainya harus melalui beberapa tahapan atau kondisi. Pendidikan formal masih belum memadai untuk mencapai kemampuan yang profesional. Untuk itu kemampuan SDM karyawan harus diberdayakan melalui peningkatkan disiplin, pelatihan, pendidikan dan pengembangan. Dengan kemampuan kerja yang memadai diharapkan memberikan implikasi terhadap peningkatan kinerja Pegawai sehingga mendukung pelaksanaan tugas secara efektif, efisien, dan profesional.

Dalam rangka meningkatkan kinerja karyawan sangat dipengaruhi disiplin Pegawai. Disiplin sendiri merupakan satu dari beberapa faktor yang mempengaruhi kinerja Pegawai. Karena tanpa adanya disiplin, maka segala kegiatan yang akan dilakukan akan mendatangkan hasil yang kurang memuaskan dan tidak sesuai dengan harapan yang mengakibatkan kurangnya pencapaian sasaran dan tujuan organisasi sehingga menghambat jalannya program organisasi yang dibuat.

Pegawai yang mempunyai tingkat kedisiplinan yang tinggi akan tetap bekerja dengan baik walaupun tanpa diawasi oleh atasan, tidak akan mencuri waktu kerja untuk melakukan hal-hal lain yang tidak ada kaitannya dengan pekerjaan serta mentaati peraturan yang ada dalam lingkungan kerja dengan kesadaran yang tinggi tanpa ada rasa paksaan. Pada akhirnya pegawai yang mempunyai kedisiplinan kerja yang tinggi akan mempunyai kinerja yang baik bila dibanding dengan para pegawai yang bermalas-malasan karena waktu kerja dimanfaatkannya sebaik mungkin untuk melaksanakan pekerjaan sesuai dengan target yang telah ditetapkan.

Selain faktor disiplin, program pelatihan yang intensif perlu dilaksanakan oleh organisasi untuk meningkatkan kinerja pegawai secara optimal. Dengan adanya kegiatan pelatihan, pegawai 
memiliki kesempatan untuk menyerap pengetahuan atau nilai-nilai baru, sehingga dengan pengetahuan baru tersebut para karyawan dapat meningkatkan profesinya dalam melaksanakan tugas yang dibebankan kepadanya. Pengembangan sumber daya manusia yang dilakukan melalui pelatihan merupakan suatu usaha untuk meningkatkan kualitas sumber daya manusia. Pelatihan merupakan hal yang sangat penting yang dapat dilakukan oleh organisasi tersebut memiliki tenaga kerja yang pengetahuan (knowledge), kemampuan (ability), dan keterampilan (skill) dapat memenuhi kebutuhan organisasi di masa kini dan di masa yang akan datang. Untuk keberhasilan program pelatihan harus didukung berbagai aspek antara lain: kesesuaian silabus dengan kebutuhan pelatihan, kualitas pelatih atau instruktur, kualitas peserta, kelengkapan sarana dan prasarana yang sesuai dalam melaksanakan kegiatan pelatihan yang simetris serta penyediaan biaya.

Begitupun yang terjadi pada Pegawai Pemadam Kabupaten Sidrap merupakan salah satu instansi pemerintah di bidang pencegahan dan pemadaman kebakaran di wilayah Kabupaten sidrap. Dalam institusi ini yang menjadi hal penting adalah Pegawai lapangan yang langsung terjung menangani masalah kebakaran yang sudah pasti berisiko besar bahkan bisa menimbulkan korban jiwa jika tidak berhati-hati dalam melaksanakannya karena keterlambatan di lokasi kebakaran dan kurang terampil sewaktu melaksanakan tugasnya. Kurangnya kinerja pegawai tidak terlepas pelatihan-pelatihan yang diberikan pimpinan. Saat ini masih ada Pegawai yang belum mendapatkan pelatihan. Selain itu, kinerja pegawai berdampak terhadap kepuasan masyarakat yang merasa apabila terjadi kebakaran cenderung merasa kecewa atas keterlambatan Pegawai dan kurangnya sarana yang mendukung dalam melaksanakan tugas.

Bertitik tolak dari pemikiran ini, maka peningkatan kinerja aparatur merupakan hal yang mendesak untuk dilaksanakan dewasa ini.

Disiplin kerja sangat penting bagi pegawai yang bersangkutan maupun bagi organisasi karena disiplin kerja akan mempengaruhi produktivitas kerja pegawai. Oleh karena itu, pegawai merupakan motor penggerak utama dalam organisasi. Disiplin kerja yang baik mencerminkan besarnya rasa tanggung jawab sesorang terhadap tugas-tugas yang diberikan kepadanya.

Disiplin kerja adalah suatu keadaan tertib dimana keadaan seseorang atau sekelompok orang yang tergabung dalam organisasi tersebut berkehendak mematuhi dan menjalankan peraturan-peraturan perusahaan baik yang tertulis maupun tidak tertulis dengan dilandasi kesadaran dan keinsyafan akan tercapainya suatu kondisi antara keinginan dan kenyataan dan 
diharapkan agar para pegawai memiliki sikap disiplin yang tinggi dalam bekerja sehingga produktivitasnya meningkat.

Banyak faktor yang berpengaruh terhadap kedisiplinan kerja karyawan. Faktor-faktor tersebut adalah :

1) Adanya tujuan yang jelas dari perusahaan

2) Adanya peraturan yang dimiliki perusahaan

3) Perilaku kedisiplinan atasan

4) Adanya Perhatian dan pengarahan kepada karyawan

5) Adanya pengawasan kepada karyawan

6) Adanya reward and punishment

7) Besar kecilnya kompensasi

Menurut Sutrisno (2009), ada 4 (empat) indikator disiplin kerja, diantaranya yaitu:

1) Taat terhadap aturan waktu. Ini dilihat dari jam masuk kerja, jam pulang, dan jam istirahat yang tepat waktu sesuai dengan aturan yang berlaku di perusahaan.

2) Taat terhadap peraturan perusahaan. Peraturan dasar tentang cara berpakaian, dan bertingkah laku dalam pekerjaan.

3) Taat terhadap aturan perilaku dalam pekerjaan. Ini ditunjukkan dengan cara melakukan pekerjaan sesuai dengan jabatan, tugas, dan tanggung jawab serta cara berhubungan dengan unit kerja lain.

4) Taat terhadap peraturan lainnya di perusahaan. Aturan mengenai apa yang boleh dan apa yang tidak boleh dilakukan oleh para pegawai dalam perusahaan.

Pelatihan adalah upaya organisasi yang berencana atau sistematis untuk meningkatkan kemampuan, keterampilan, pengetahuan dan dapat mengubah sikap Pegawai kearah yang lebih baik sehingga Pegawai mampu melaksanakan tugas dan tanggung jawabnya.

Pelatihan saat ini sudah menjadi salah satu peluang bisnis menarik sehingga banyak orang yang memilih professi sebagai event organizer dan instruktur pelatihan. Menurut Machmed Tun Ganyang (2018) Berdasarkan tempat pelaksanaan pelatihan, maka pelatihan dapat dibagi menjadi dua jenis, yaitu: pelatihan di dalam perusahaan dan pelatihan di luar perusahaan.

Berdasarkan aplikasi manfaat pelatihan, maka pelatihan dapat dibagi menjadi dua jenis, yaitu: pelatihan aplikasi langsung dan pelatihan untuk pelatih. 
Menurut Machmed Tun Ganyang (2018) Terdapat beberapa manfaat dari pelaksanaan pelatihan oleh perusahaan, antara lain:

1) Produktivitas karyawan diharapkan menjadi lebih efektif setelah mengikuti program pelatihan.

2) Melalui pelatihan standar kerja karyawan diharapkan tercapai dengan waktu yang lebih efisien.

3) Latihan dapat menghemat biaya perawatan peralatan atau mesin karena ditangani oleh karyawan yang terlatih.

4) Latihan dapat menciptakan sikap, loyalitas, dan kerjasama yang lebih menguntungkan antar sesama karyawan.

5) Latihan dapat memotivasi karyawan untuk memenuhi syarat guna pengembangan sumberdaya manusia, sehingga karyawan akan terus memperbaiki diri.

6) Latihan dapat mencegah sikap antipati karyawan terhadap perusahaan.

7) Latihan merupakan langkah terbaik dalam rangka mencegah atau mengurangi terjadinya kecelakaan kerja dalam suatu perusahaan sehingga akan menciptakan suasana kerja yang tenang dan aman.

8) Pelatihan akan mendorong Inisiatif dan kreativitas karyawan. Hal ini akan meningkatkan kemampuan yang dimiliki oleh karyawan dalam menyesuaikan diri dengan perkembangan teknologi.

9) Pemberian kesempatan pada karyawan untuk mengikuti pelatihan dapat diartikan sebagai pemberian balas jasa atas prestasi yang telah dicapai pada waktu yang lalu.

10) Latihan dapat menjadi satu cara untuk mengurangi perputaran tenaga kerja di perusahaan. Menurut Mangkunegara (2013)menyatakan bahwa faktor-faktor yang diperlukan dalam pelatihan dan pengembangan antara lain:

a) Perbedaan individu pegawai.

b) Hubungan dengan jabatan analisis.

c) Motivasi.

d) partisipasi aktif.

e) Seleksi peserta penataran.

f) Metode pelatihan dan pengembangan. 
Kinerja merupakan aktivitas pegawai dalam melakukan pekerjaan dan hasil yang dicapai dari pekerjaan tersebut atau tentang apa yang dikerjakan dan bagaimana cara mengerjakannya.

Dalam organisasi modern, penilaian kerja pegawai sangat penting dilakukan dalam arti disamping mengetahui kemajuan tentang hasil yang dicapai pegawai secara keseluruhan juga sangat bermanfaat bagi organisasi terutama dalam pemberian penghargaan. Evaluasi kinerja merupakan prestasi individu yang merupakan cerminan prestasi organisasi, oleh karena itu prestasi pegawai yang tinggi sangat penting artinya bagi keberhasilan organisasi.

Penilaian prestasi kerja yang rasional dan diterapkan secara obyektif terikat minimal dua kepentingan, yaitu kepentingan pegawai yang bersangkutan dan kepentingan organisasi. Evaluasi kinerja harus mempunyai tujuan yang jelas tentang apa yang ingin dicapai baik tidaknya suatu prestasi dapat diketahui melalui penilaian. Evaluasi kinerja harus mempunyai tujuan yang jelas tentang apa yang ingin dicapai, baik tidaknya suatu prestasi dapat diketahui melalui penilaian.

Adapun menurut Robbins (2006) kinerja karyawan memiliki enam indikator, yaitu:

1) Kualitas. Kualitas kerja diukur dari persepsi karyawa terhadap kualitas pekerjaan yang dihasilkan serta kesempurnaan tugas terhadap keterampilan dan kemampuan karyawan.

2) Kuantitas. Merupakan jumlah yang dihasilkan dinyatakan dalam istilah seperti jumlah unit, jumlah siklus aktivitas yang diselesaikan.

3) Ketepatan Waktu. Merupakan tingkat aktivitas diselesaikan pada awal waktu yang dinyatakan, dilihat dari sudut koordinasi dengan hasil output serta memaksimalkan waktu yang tersedia untuk aktivitas lain.

4) Efektivitas. Merupakan tingkat penggunaan sumber daya organisasi (tenaga, uang, teknologi, bahan baku) dimaksimalkan dengan maksud menaikkan hasil dari setiap unit dalam penggunaan sumber daya.

5) Kemandirian. Merupakan tingkat seseorang karyawan yang nantinya akan dapat menjalankan tugas kerjanya.

6) Komitmen kerja. Merupakan suatu tingkat dimana karyawan mempunyai komitme kerja dengan instansi dan tanggung jawab karyawan terhadap kantor.

11) Berdasarkan pendapat di atas tersebut, maka dapat disimpulkan bahwa Pegawai atau kelompok akan mampu mencapai kinerja

organisasi secara maksimal (output) apabila didukung dengan kemampuan (ability) yang baik dan motivasi kerja yang tinggi. Sikap pimpinan dan pegawai serta fasilitas kerja haruslah 
memadai supaya Pegawai mampu mengaktualisasikan dirinya untuk mencapai tujuan yang diinginkan. Selain itu faktor hubungan antara Pegawai dengan Pegawai lain dan Pegawai dengan pimpinan (organisasi) turut mempengaruhi hasil kerja Pegawai.

\section{METODE PENELITIAN}

Penelitian ini dilakukan pada kantor UPTD Pemadam Kebakaran Kabupaten Sidrap yang berlokasi di Jln. Paccekke Kecamatan Maritengngae. Populasi yang digunakan dalam penelitian ini adalah Pegawai pemadam kebakaran yang terlibat langsung ke lapangan, di UPTD Pemadam Kebakaran Kabupaten Sidrap terdiri dari 13 pegawai ASN dan 113 honorer jadi jumlah keseluruhan pegawai adalah 126 orang anggota. jumlah sampel dalam penelitian ini sebanyak 56 orang pegawai. maka dalam penelitian ini digunakan teknik sampling yaitu sampling jenuh (sensus), dimana semua anggota populasi dijadikan sampel.

Analisis data yang digunakan dalam penelitian ini adalah analisis kuantitatif dan analisis kualitatif. Analisis kuantitatif dilakukan dengan pengujian statistik dari hasil kuesioner kemudian hasil penguji tersebut akan dijelaskan dengan menggunakan kalimatkalimat. Dengan kata lain, analisis kuantitatif terlebih dahulu digunakan kemudian dilanjutkan dengan analisis kualitatif.

Analisis kuantitatif digunakan untuk melihat hasil kuesioner dengan menggunakan tabulasi (tabelaris) yang berupa penilaian dari hasil pengisian kuesioner. Pengujian hipotesis yang dilakukan dalam penelitian ini, adalah dilakukan dengan metode regresi linear yang digunakan untuk memprediksi seberapa jauh perubahan nilai variabel dependen, bila variabel independen dimanipulasi/ dirubah-rubah atau dinaikturunkan. (Sugiyono, 2014)

Rumus Regresi Linear Berganda sebagai berikut;

$$
\mathbf{Y}=\mathbf{a}+\mathbf{b} 1 \mathbf{X} 1+\mathbf{b} 2 \mathrm{X} 2+\mathrm{e}
$$

Dimana :

$$
\begin{array}{ll}
\mathrm{Y} & =\text { Kinerja Pegawai } \\
\mathrm{a} & =\text { Konstanta } \\
\mathrm{b} 1, \mathrm{~b} 2 & =\text { Koefisien Regresi } \\
\mathrm{X} 1 & =\text { Disiplin Kerja } \\
\mathrm{X} 2 & =\text { Pelatihan Kerja } \\
\mathrm{e} & =\text { Standart Error }
\end{array}
$$




\section{HASIL DAN PEMBAHASAN}

\section{a. Uji Validitas}

Uji validitas digunakan untuk mengetahui seberapa cermat suatu instrumen atau item-item dalam mengukur apa yang ingin diukur. Item kuisioner yang tidak valid berarti tidak dapat mengukur apa yang ingin diukur sehingga hasil yang didapat tidak dapat dipercaya, sehingga item yang tidak valid harus dibuang atau diperbaiki. Uji validitas yang banyak digunakan yaitu dengan metode korelasi Person yaitu mengkorelasikan antara skor tiap item dengan skor total item.

Jika pengambilan keputusan berdasarkan nilai korelasi, maka dicari dulu nilai $r$ tabelnya, $r$ tabel dapat dilihat pada tabel statistik dengan uji 2 sisi, pada $n=56$ atau $\mathrm{df}=56-2=54(\mathrm{df}=\mathrm{n}-$ k) didapat nilai $r$ tabel $=0,279$. Selanjutnya dibandingkan antara $r$ hitung dengan $r$ tabel sebagai berikut :

Tabel 1. Analisis Validasi Variabel Kedisiplinan (X.1)

\begin{tabular}{|c|c|c|c|c|}
\hline $\begin{array}{c}\text { Nomor } \\
\text { Butir }\end{array}$ & $\begin{array}{c}\text { Korelasi } \\
\text { Item } \\
\text { Total } \\
(\mathbf{r} \\
\text { hitung) }\end{array}$ & Sig & $\begin{array}{c}\mathbf{r} \\
\text { tabel }\end{array}$ & Keterangan \\
\hline X1.1 & 0,505 & 0,000 & 0,279 & Valid \\
\hline X1.2 & 0,717 & 0,000 & 0,279 & Valid \\
\hline X1.3 & 0,666 & 0,000 & 0,279 & Valid \\
\hline X1.4 & 0,750 & 0,000 & 0,279 & Valid \\
\hline X1.5 & 0,651 & 0,000 & 0,279 & Valid \\
\hline X1.6 & 0,592 & 0,000 & 0,279 & Valid \\
\hline X1.7 & 0,663 & 0,000 & 0,279 & Valid \\
\hline
\end{tabular}

Sumber: Analisis Validasi

Berdasarkan tabel 1 di atas menunjukkan bahwa seluruh pernyataan dalam variabel Kedisplinan (X1) adalah valid. Hal ini terlihat bahwa nilai pearson correlation ( $\mathrm{r}$ hitung) setiap item pernyataan lebih besar dari nilai $r$ tabel dengan tingkat signifikansi untuk semua item pernyataan pada level lebih kecil dari 0,05. Selanjutnya analisis validasi pada variabel pelatihan kerja (X.2) dapat dilihat pada tabel 2 di bawah ini:

Tabel 2. Analisis Validasi Variabel Pelatihan Kerja (X.2)

\begin{tabular}{|c|c|c|c|c|}
\hline $\begin{array}{c}\text { Nomor } \\
\text { Butir }\end{array}$ & $\begin{array}{c}\text { Korelasi } \\
\text { Item Total } \\
(\mathbf{r} \text { hitung) }\end{array}$ & Sig & r table & Keterangan \\
\hline $\mathrm{X} 2.1$ & 0,737 & 0,000 & 0,279 & Valid \\
\hline $\mathrm{X} 2.2$ & 0,769 & 0,000 & 0,279 & Valid \\
\hline
\end{tabular}




\begin{tabular}{|c|c|c|c|c|}
\hline X2.3 & 0,812 & 0,000 & 0,279 & Valid \\
\hline X2.4 & 0,701 & 0,000 & 0,279 & Valid \\
\hline X2.5 & 0,718 & 0,000 & 0,279 & Valid \\
\hline X2.6 & 0,699 & 0,000 & 0,279 & Valid \\
\hline X2.7 & 0,773 & 0,000 & 0,279 & Valid \\
\hline
\end{tabular}

\section{Sumber: Analisis Validasi}

Berdasarkan tabel 2 di atas menunjukkan bahwa seluruh pernyataan dalam variabel pelatihan kerja (X2) adalah valid. Hal ini terlihat bahwa nilai pearson correlation ( $\mathrm{r}$ hitung) setiap item pernyataan lebih besar dari nilai $r$ tabel dengan tingkat signifikansi untuk semua item pernyataan pada level lebih kecil dari 0,05 . Selanjutnya analisis validasi pada variabel kinerja (Y) dapat dilihat pada tabel 3 di bawah ini :

Tabel 3. Analisis Validasi Variabel Kinerja (Y)

\begin{tabular}{|c|c|c|c|c|}
\hline $\begin{array}{c}\text { Nomor } \\
\text { Butir }\end{array}$ & $\begin{array}{c}\text { Korelasi } \\
\text { Item Total } \\
\text { (r hitung) }\end{array}$ & Sig & r tabel & Keterangan \\
\hline Y.1 & 0,540 & 0,000 & 0,279 & Valid \\
\hline Y.2 & 0,818 & 0,000 & 0,279 & Valid \\
\hline Y.3 & 0,586 & 0,000 & 0,279 & Valid \\
\hline Y.4 & 0,684 & 0,000 & 0,279 & Valid \\
\hline Y.5 & 0,701 & 0,000 & 0,279 & Valid \\
\hline Y.6 & 0,652 & 0,000 & 0,279 & Valid \\
\hline Y.7 & 0,737 & 0,000 & 0,279 & Valid \\
\hline
\end{tabular}

Sumber: Analisis Validasi

Berdasarkan tabel 3 di atas menunjukkan bahwa seluruh pernyataan dalam variabel kinerja (Y) adalah valid. Hal ini terlihat bahwa nilai pearson correlation ( $\mathrm{r}$ hitung) setiap item pernyataan lebih besar dari nilai $r$ tabel dengan tingkat signifikansi untuk semua item pernyataan pada level lebih kecil dari 0,05 .

\section{b. Uji Realibilitas}

Uji realibilitas digunakan untuk menguji konsistensi alat ukur, apakah hasilnya tetap konsisten atau tidak jika pengukuran diulang. Uji reliabilitas yang dilakukan pada penelitian ini yaitu menggunakan metode Cronbach Alpha, Metode pengambilan keputusan untuk uji reliabilitas menggunakan batasan 0,6. Menurut Sekaran (1992) dikutip dalam Duwi Priyatno “Belajar Alat Analisis Data dan Cara Pengolahannya Dengan SPSS” (2016; 158), reliabilitas kurang dari 0,6 adalah kurang baik. Sedangkan 0,7 dapat diterima dan diatas 0,8 adalah baik. 
Tabel 4. Hasil Pengujian Reliabilitas

\begin{tabular}{|l|c|c|}
\hline \multicolumn{1}{|c|}{ Variabel } & Alpha & Keterangan \\
\hline $\begin{array}{l}\text { Kedisplinan } \\
\text { (X1) }\end{array}$ & 0,758 & $\begin{array}{c}\text { Reliabel / dapat } \\
\text { diterima }\end{array}$ \\
\hline $\begin{array}{l}\text { Pelatihan Kerja } \\
\text { (X2) }\end{array}$ & 0,783 & $\begin{array}{c}\text { Reliabel / dapat } \\
\text { diterima }\end{array}$ \\
\hline $\begin{array}{l}\text { Kinerja } \\
\text { Pegawai (Y) }\end{array}$ & 0,767 & $\begin{array}{c}\text { Reliabel / dapat } \\
\text { diterima }\end{array}$ \\
\hline
\end{tabular}

Sumber : Data primer yang diolah, 2020

Berdasarkan tabel 4 diatas menunjukkan bahwa semua variabel mempunyai Cronbach Alpha yang cukup besar yaitu di atas 0,60 sehingga dapat dikatakan semua konsep pengukur masing-masing variabel dari kuesioner adalah reliabel sehingga untuk selanjutnya item-item pada masing-masing konsep variabel tersebut reiabel atau hasilnya akan konsisten jika diukur ulang.

\section{c. Uji Parsial (Uji T)}

Uji t digunakan untuk menguji pengaruh variabel independen secara parsial terhadap variabel dependen. Hasil uji t pada penelitian ini dapat dilihat pada tabel 5.

Tabel 5. Uji Hipotesis Parsial

Coefficients $^{\mathbf{a}}$

\begin{tabular}{|c|c|c|c|c|c|}
\hline \multirow[t]{2}{*}{ Model } & \multicolumn{2}{|c|}{$\begin{array}{l}\text { Unstandardi } \\
\text { zed } \\
\text { Coefficients }\end{array}$} & $\begin{array}{c}\text { Standar } \\
\text { dized } \\
\text { Coeffici } \\
\text { ents }\end{array}$ & \multirow[t]{2}{*}{$\mathrm{T}$} & \multirow[t]{2}{*}{ Sig. } \\
\hline & B & $\begin{array}{l}\text { Std. } \\
\text { Error }\end{array}$ & Beta & & \\
\hline $\begin{array}{l}\text { (Con } \\
\text { stant) }\end{array}$ & 8,501 & 2,746 & & 3,095 & $\begin{array}{r}, 00 \\
3\end{array}$ \\
\hline $1 \mathrm{X} 1$ & , 160 & , 146 & , 171 & 1,097 & $\begin{array}{r}, 00 \\
2\end{array}$ \\
\hline X 2 & ,502 & 137, & ,572 & 3,661 & $\begin{array}{r}, 00 \\
1\end{array}$ \\
\hline
\end{tabular}

a. Dependent Variable: Kinerja

Sumber : Data primer yang diolah, 2020

Sebelum menyimpulkan output untuk uji parsial, terlebih dahulu mencari nilai $\mathrm{t}$ tabel. Dimana $\mathrm{df}=\mathrm{n}-\mathrm{k}$ dimana $\mathrm{df}=56-2=54$ didapat nilai $\mathrm{t}$ tabel $=0,679$. Apabila $\mathrm{t}$ hitung $>\mathrm{t}$ tabel 
maka variabel independen memiliki pengaruh terhadap variabel dependen dan jika thitung $<\mathrm{t}$ tabel maka variabel independen tidak memiliki pengaruh terhadap variabel dependen.

Berdasarkan hasil uji parsial untuk variabel kedisiplinan diperoleh $\mathrm{t}=1,097$ lebih besar dari t tabel $=0,679$, kemudian dengan nilai signifikansi sebesar 0,002 yang berarti $<0,05$. Hal ini menunjukan bahwa ada signifikan kedisiplinan terhadap kinerja pegawai secara parsial.

Berdasarkan hasil uji parsial untuk variabel pelatihan kerja diperoleh $\quad t=3,661$ jauh lebih besar dari t tabel $=0,679$ kemudian dengan nilai signifikansi sebesar 0,001 yang jauh lebih kecil dari 0.05 dapat disimpulkan bahwa ada signifikan pelatihan kerja terhadap kinerja pegawai secara parsial.

Dapat disimpulkan secara parsial bahwa variabel Kedisiplinan $\left(\mathrm{X}_{1}\right)$ dan variabel pelatihan kerja $\left(\mathrm{X}_{2}\right)$ mempunyai pengaruh yang signifikan terhadap kinerja pegawai pada UPTD Pemadam Kebakaran Kabupaten Sidrap.

\section{d. Uji Simultan (Uji F)}

Uji $F$ digunakan untuk menguji dan mengetahui seberapa besar pengaruh variabel independen secara bersama-sama terhadap variabel dependen. Hasil perhitungan regresi secara simultan dapat dilihat pada tabel 6 berikut :

Tabel 6. Hasil Analisis Regresi secara Simultan ANOVA $^{\mathrm{a}}$

\begin{tabular}{|c|c|c|c|c|c|}
\hline Model & $\begin{array}{l}\text { Sum of } \\
\text { Squares }\end{array}$ & Df & $\begin{array}{l}\text { Mean } \\
\text { Square }\end{array}$ & $\mathrm{F}$ & Sig. \\
\hline $\begin{array}{l}\text { Regress } \\
\text { ion }\end{array}$ & 304,239 & 2 & 152,120 & $\begin{array}{r}23,94 \\
5\end{array}$ & $\begin{array}{r}, 00 \\
0^{\mathrm{b}}\end{array}$ \\
\hline $\begin{array}{l}\text { Residua } \\
1\end{array}$ & 298,581 & 53 & 6,353 & & \\
\hline Total & 602,820 & 55 & & & \\
\hline
\end{tabular}

a. Dependent Variable: Kinerja

b. Predictors: (Constant), Kedisiplinan, Pelatihan Kerja

Sumber : Data primer yang diolah, 2020

Pengujian pengaruh variabel bebas secara bersama-sama terhadap variabel terikatnya dilakukan dengan menggunakan uji $\mathrm{F}$. Hasil perhitungan statistik menunjukkan nilai $\mathrm{F}$ hitung $=$ 23,945 dengan signifikansi sebesar $0,000<0,05$. Hal ini berarti bahwa kedisiplinan dan 
pelatihan kerja mempunyai pengaruh secara bersama-sama dan signifikan terhadap kinerja pegawai pada UPTD Pemadam Kebakaran Kabupaten Sidrap.

\section{e. Analisis Regresi Linear Berganda}

Analisis regresi linear berganda digunakan dalam penelitian ini dengan maksud dan tujuan untuk membuktikan hipotesis mengenai pengaruh variabel kedisiplinan dan pelatihan kerja secara parsial maupun secara simultan terhadap kinerja pegawai pada UPTD Pemadam Kebakaran Kabupaten Sidrap.

Perhitungan statistik dalam penelitian analisis regresi linear berganda yang digunakan dalam penelitian ini adalah dengan menggunakan bantuan program komputer SPSS for windows versi 20. Hasil pengolahan data dengan menggunakan program SPSS selengkapnya ada pada lampiran dan selanjutnya dijelaskan pada tabel 7 berikut ini :

\section{Tabel 7. Analisis Regresi Linear Baerganda}

Coefficients $^{\mathrm{a}}$

\begin{tabular}{|c|c|c|c|c|c|}
\hline \multirow{3}{*}{ Model } & \multicolumn{2}{|c|}{$\begin{array}{l}\text { Unstandardized } \\
\text { Coefficients }\end{array}$} & \multirow{3}{*}{\begin{tabular}{|c|}
$\begin{array}{c}\text { Standar } \\
\text { dized } \\
\text { Coeffici } \\
\text { ents }\end{array}$ \\
Beta \\
\end{tabular}} & \multirow{3}{*}{$\mathrm{T}$} & \multirow{3}{*}{ Sig. } \\
\hline & & & & & \\
\hline & B & $\begin{array}{l}\text { Std. } \\
\text { Error }\end{array}$ & & & \\
\hline $\begin{array}{l}\text { (Con } \\
\text { stant) }\end{array}$ & 8,501 & 2,746 & & 3,095 & ,003 \\
\hline X 1 & 160 & 146, & ,171 & 1,097 & ,002 \\
\hline X 2 &, 502 & ,137 & ,572 & 3,661 & ,001 \\
\hline
\end{tabular}

a. Dependent Variable: Kinerja

Sumber : Data primer yang diolah, 2020

Model persamaan regresi yang dapat dituliskan dari hasil standardized coefficients tersebut, persamaan regresinya sebagai berikut :

$$
Y=8,501+0,160 X_{1}+0,502 X_{2}
$$

Persamaan regresi diatas dapat dijelaskan sebagai berikut bahwa Koefisien regresi variabel Kedisiplinan $\left(\mathrm{X}_{1}\right)$ mempunyai nilai koefisien beta sebesar 0,160 dan bernilai positif. Setiap kenaikan variabel kedisiplinan sebesar 1, maka diikuti kenaikan kinerja pegawai sebesar 0,160 dengan asumsi variabel lainnya tetap atau konstan. Koefisien regresi variabel pelatihan kerja $\left(\mathrm{X}_{2}\right)$ memiliki nilai beta sebesar 0,502 dan bernilai positif. Setiap kenaikan variabel pelatihan 
kerja sebesar 1, maka diikuti dengan kenaikan kinerja pegawai sebesar 0,502 dengan asusmsi variabel lainnya tetap atau konstan.

\section{f. Koefisien Determinasi}

Analisis $\mathrm{R}^{2}$ (R Square) atau koefisien determinasi digunakan untuk mengetahui seberapa besar prosentase sumbangan pengaruh variabel independen secara bersama-sama terhadap variabel dependen. Nilai koefisien determinasi ditentukan dengan nilai adjusted $\mathrm{R}$ square pada tabel 12 berikut.

Tabel 8. Koefisien Detrminasi $\left(\mathrm{R}^{2}\right)$

Model Summary

\begin{tabular}{|c|c|c|c|c|}
\hline Model & $\mathbf{R}$ & R Square & $\begin{array}{c}\text { Adjusted R } \\
\text { Square }\end{array}$ & $\begin{array}{c}\text { Error } \\
\text { of the } \\
\text { Estim } \\
\text { ate }\end{array}$ \\
\hline 1 &, $710^{\mathrm{a}}$ &, 505 &, 484 & 2,520 \\
\hline
\end{tabular}

a. Predictors: (Constant), kedisiplinan, pelatihan kerja

Sumber : Data primer yang diolah, 2020

Hasil perhitungan SPSS dapat diketahui bahwa $R$ square yang diperoleh sebesar 0,505. Hal ini berarti 50,5 \% kinerja pegawai UPTD Pemadam Kebakaran Kabupaten Sidrap dipengaruhi oleh kedisiplinan dan pelatihan kerja. Sedangkan sisanya yang sebesar 49,5\%, dipengaruhi oleh variabel-variabel lainnya yang tidak diteliti dalam penelitian ini.

Kedisiplinan, pelatihan kerja dan kinerja merupakan hal yang mendasar harus dimiliki oleh seorang pegawai dalam bekerja diinstansi pemerintah maupun swasta. Salah satu faktor yang mempengaruh kinerja adalah disiplin kerja. Disiplin kerja di dalam suatu organisasi bertujuan agar semua pegawai yang ada dalam perusahaan tersebut bersedia dengan sukarela mematuhi serta mentaati setiap tata tertib yang berlaku tanpa ada paksaan. Disiplin kerja yang baik dapat dilihat dari tingginya kesadaran para karyawannya dalam mematuhi serta mentaati segala peraturan dan tata tertib yang berlaku. Sedangkan untuk pelatihan kerja, materi pelatihan dan pengembangan harus disesuaikan dengan tingkat kemampuan pegawai yang menjadi peserta, metode pelatihan dan pengembangan harus disesuaikan dengan tingkat kemampuan pegawai yang menjadi peserta dan peserta pelatihan dan pengembangan harus memenuhi persyaratan yang ditentukan. Yang pada akhirnya nanti tingkat kedisiplinan dan pelatihan kerja pegawai akan mempengaruhi dan menunjang kinerja pegawai itu sendiri dimasa yang akan datang. 
1) Kedisiplinan secara parsial berpengaruh terhadap kinerja pegawai pada kantor UPTD Pemadam Kebakaran Kabupaten Sidrap. dimana hasil uji parsial untuk variabel Kedisiplinan diperoleh $\mathrm{t}=1,097$ lebih besar dari $\mathrm{t}$ tabel $=0,679$, kemudian dengan nilai signifikansi sebesar 0,002 yang berarti $<0,05$. Maka Ha1 pada penelitian ini dinyatakan bahwa kedisiplinan mempunyai pengaruh terhadap kinerja pegawai pada Kantor UPTD Pemadam Kebakaran Kabupaten Sidrap, dimana terbukti kebenarannya maka Ha1 diterima dan Ho1 ditolak.

2) Pelatihan kerja secara parsial berpengaruh terhadap kinerja pegawai Kantor UPTD Pemadam Kebakaran kabupaten Sidrap diman hasil uji parsial untuk variabel pelatihan kerja diperoleh $\mathrm{t}=3,661$ jauh lebih besar dari $\mathrm{t}$ tabel $=0,679$ kemudian dengan nilai signifikansi sebesar 0,001 yang jauh lebih kecil dari 0.05 Maka Ha2 pada penelitian ini dinyatakan bahwa kedisiplinan mempunyai pengaruh terhadap kinerja pegawai pada Kantor UPTD Pemadam Kebakaran Kabupaten Sidrap, dimana terbukti kebenarannya maka Ha2 diterima dan Ho1 ditolak.

3) Kedisiplinan dan Pelatihan kerja secara bersama-sama berpengaruh terhadap variabel kinerja. Hal ini dapat dilihat kedisiplinan dan pelatihan kerja menunjukkan nilai $\mathrm{F}$ hitung $=23,945$ dengan signifikansi sebesar $0,000<0,05$. Maka dalam penelitian ini dapat dinyatakan bahwa kedisiplinan dan pelatihan kerja mempunyai pengaruh secara bersama-sama dan signifikan terhadap kinerja pegawai pada UPTD Pemadam Kebakaran Kabupaten Sidrap, terbukti kebenarannya $\mathrm{Ha} 3$ diterima dan $\mathrm{Ho} 3$ ditolak.

\section{KESIMPULAN DAN SARAN}

Kesimpulan dari hasil penelitian ini adalah sebagai berikut :

1) Kedisiplinan secara parsial berpengaruh terhadap kinerja pegawai pada kantor UPTD Pemadam Kebakaran Kabupaten Sidrap. dimana hasil uji parsial untuk variabel Kedisiplinan diperoleh $\mathrm{t}=1,097$ lebih besar dari $\mathrm{t}$ tabel $=0,679$, kemudian dengan nilai signifikansi sebesar 0,002 yang berarti $<0,05$.

2) Pelatihan kerja secara parsial berpengaruh terhadap kinerja pegawai Kantor UPTD Pemadam Kebakaran kabupaten Sidrap diman hasil uji parsial untuk variabel pelatihan kerja diperoleh $\mathrm{t}$ $=3,661$ jauh lebih besar dari $\mathrm{t}$ tabel $=0,679$ kemudian dengan nilai signifikansi sebesar 0,001 yang jauh lebih kecil dari 0.05 . 
3) Kedisiplinan dan Pelatihan kerja secara bersama-sama berpengaruh terhadap variabel kinerja. Hal ini dapat dilihat kedisiplinan dan pelatihan kerja menunjukkan nilai $\mathrm{F}$ hitung $=23,945$ dengan signifikansi sebesar $0,000<0,05$.

Adapun saran dalam penelitian ini adalah:

1) Bagi peneliti diharapkan dapat mempraktekkan hasil penelitian di perusahaan tempat peneliti bekerja.

2) Bagi institusi, disarankan agar dapat mempublikasikan hasil penelitian ini yang nantinya dapat dijadikan sebagai bahan acuan bagi peneliti selanjutnya

3) Bagi UPTD Pemadam Kebakaran Kabupaten Sidrap Kinerja pegawai secara keseluruhan sangat dipengaruhi oleh pelatihan dan disiplin kerja. Peningkatan kedua variabel tersebut baik secara terpisah (parsial) maupun bersamasama (simultan) dapat meningkatkan kinerja pegawai secara maksimal. Maka disarankan agar UPTD Pemadam Kebakaran Kabupaten Sidrap dapat meningkatkan dan memperbaiki kedua variabel tersebut di dalam instansi tersebut.

4) Untuk penelitian selanjutnya, disarankan untuk meneliti objek penelitian yang memiliki hasil lebih signifikan dengan menambah variabel lain di luar penelitian ini yang mempengaruhi kinerja karyawan

\section{DAFTAR PUSTAKA}

Astadi Pangarso, Putri Intan Susanti, 2016. Pengaruh Disiplin Kerja Terhadap kinerja Pegawai Di Biro Pelayanan Sosoal Dasar Sekretariat Daerah Provensi Jawa Barat. Jurnal Manajemen Teori dan Terapan. 9, 1-16.

Astri Wulandari, 2008, Skripsi, Pengaruh Pelatihan dan Disiplin Kerja Terhadap Kinerja Karyawan pada Yayasan Pendidikan Telkom.

Devito, Joshep A, 2011. Manajemen Sumber Daya Manusia. Tangerang Selatan: Karisma Publishing Group.

Edy Sutrisno, 2016. Manajemen Sumber Daya Manusia. Jakarta: Kencana.

Hasibuan, Malayu, SP, 2008. Manajemen Sumber Daya Manusia. Jakarta: Bumi Aksara.

Hadari Nawawi, 2012. Manajemen Sumber Daya Manusia Untuk Bisnis yang Kompetitif. Gaja Mada University Press. Yogyakarta.

Heni Heryani, 2012, Skripsi Pengaruh Pelatihan dan Motivasi Terhadap Kinerja Karyawan Pada Perum Perumnas Regional IV Bandung.

Imam Somantri, 2014, Skripsi, Pengaruh Disiplin Kerja dan Pelatihan Terhadap Kinerja Karyawan Pada Koperasi Tirta Karya PDAM Tirta Wening Kota Bandung. 
Mariana Kristiyani, 2009., Skripsi. Pengaruh Disiplin Kerja Terhadap Kinerja Karyawan pada PT. Nyonya Meneer Semarang, Jawa Tengah.

Mangkunegara, A. A. AP, 2013. Manajemen Sumber Daya Perusahaan. Bandung: Remaja Rosdakarya.

Machmed Tun Ganyang, 2018. Manajemen Sumber Daya Manusia Konsep dan Realita. Bogor: In Media.

Sugiyono, 2014. Metode Penelitian Pendidikan (Pendekatan Kuantitatif, Kualitatif dan $R \& D$. Bandung: Alfabeta.

Sedarmayanti, 2009. Manajemen Sumber Daya Manusia Reformasi Birokrasi dan Manajemen Pegawai Negeri Sipil. Bandung: Refika Aditama.

Umam, K, 2010. Perilaku Organisasi. Bandung: Pustaka Setia.

Wibowo, 2011. Manajemen Kinerja. Jakarta: Rajawali Pres.

Yun Iswanto, Adhie Yusuf, 2018. Manajemen Ssumber Daya Manusia.Tanggerang Selatan: Universitas Terbuka 